\title{
A Comparison of Static Measures of Liquidity to Integrative Measures of Financial and Operating Liquidity: An Application to Restaurant Operators and Restaurant Franchisors
}

\author{
Linda Canina \\ Cornell University \\ Steve A. Carvell \\ Cornell University
}

\begin{abstract}
The results presented in this paper show that integrative financial and operating measures of liquidity provide investors and creditors with information beyond that provided by static measures of short-term liquidity such as the current and quick ratios. Using a sample of restaurant firms over the period 1994-2003, our analysis shows dynamic measures of liquidity provide a drastically different view of short-term solvency than those produced from the static measures. Static measures of liquidity imply that restaurant companies are not liquid. However, when evaluated under this integrative framework, restaurant companies were shown to be more liquid than their current and quick ratios implied. Thus, financial analysts, creditors, and managers should evaluate both static and dynamic liquidity measures when evaluating the short-term financial liquidity and short-term credit worthiness of firms. In addition, careful attention should be paid to both financial and operating measures of liquidity to establish what changes, if any, have occurred in a company's liquidity position over time. This is an important finding for managers and investors in all industries, since short-term illiquidity implies a high risk of default if the banks refuse to refinance all or part of the debt. This in turn may affect the cost of short-term financing and result in an impact on their overall financing costs and required returns from equity investors.
\end{abstract}

\section{Introduction}

Liquidity measurement is an important part of financial statement analysis, particularly in shortterm credit evaluations as a component of assessing credit worthiness and the likelihood of short-term solvency. The accurate measurement of a firm's liquidity is important to both creditors and investors as they consider short-term default risk in their calculations of short-term borrowing costs, credit worthiness, cost of capital, and valuation. Financial analysts and creditors considered short-term 
liquidity measures such as the current and quick ratios to be key liquidity measures. In fact, these ratios are the most commonly employed measures of a firm's liquidity (Kamath, 1989). These measures emphasize a static approach to liquidity analysis because they consider only the firm's stock of liquid resources. There exists another source of liquid resources available to the firm in meeting its short-term obligations. That is the flow of liquid resources available from operations. Operating cash flow coverage is a crucial element in liquidity analysis that is often ignored. Depending solely on the measurement characteristics of static ratios may overstate or understate the overall short-term liquidity of the firm.

In this regard, many researchers have questioned the adequacy of static liquidity measures such as the current and quick ratios. The static ratios measure the short-term liquidity of the assets, but they focus on the solvency of the firm in relation to liquidation, not the liquidity provided from financial assets and operations for the company as a going concern. In this paper, we describe and compare other measures of liquidity that estimate separately the financial and operating liquidity of the firm as a going concern.

The appropriate measurement of short-term liquidity is critical to the financial management of any firm. Operating liquidity plays an integral part in establishing short-term financial risk. As a result of the potential inadequacy of the static liquidity measures, this paper applies an integrative approach to the analysis of liquidity. The integrative approach breaks down liquidity into two components: financial liquidity and operating liquidity. The extent to which the firm's potential short-term obligations are covered by both its stock of liquid financial assets as reported on the balance sheet and its flow of liquid resources provided as a result of operations are identified separately.

This paper compares static measures of liquidity to integrative financial and operating liquidity measures in order to determine whether the integrative measures provide any information regarding the liquid reserve of the firm beyond that of the static measures. First, two of the most common static measures of liquidity are discussed, along with an analysis of the potential problems associated with them. This is followed by an explanation of the integrative approach to liquidity analysis. Then a comparison is made across the various measures of liquidity for a sample of restaurant operators and restaurant franchisors. (Note that the comparison is relative to the measures, not relative to the samples.) The paper ends with specific suggestions for analysts, investors, and executives involved in short-term liquidity analysis. 


\section{Measures of Liquidity}

A liquid reserve is maintained in order to meet cash obligations as they come due. If not enough cash is available, a firm may have to delay payments, obtain temporary financing at unfavorable terms, or even sell assets. An adequate liquid reserve protects management from having to undertake these costly actions. The purpose of liquidity analysis is to provide to managers, financial analysts, and creditors an indication of the adequacy of the liquid reserve. In order to fulfill this goal, a liquidity measure must possess at least the following two characteristics. First, the measure should convey information about the likelihood that a firm will be able to meet its cash requirements. A firm with a high value for the liquidity measure will have a high likelihood of meeting its cash obligations and hence has adequate reserves. Second, it must incorporate only resources that are truly liquid-in other words, those assets quickly and easily convertible into cash, the use of which use does not disrupt operations.

\section{Static Measures of Liquidity}

Managerial accountants most commonly suggest and use the current ratio and the quick ratio to evaluate liquidity. The current ratio is defined as current assets divided by current liabilities. The quick ratio is defined as current assets less inventory divided by current liabilities. Liquidity ratios are designed to capture the firm's liquidity based on the premise that liquidity is measured as the ratio of some or all of a firm's current assets to its current liabilities. These ratios implicitly state that the firm's current liabilities are "covered" with the firm's current assets. These ratios have one real advantage to the user: they are fairly simple to interpret. The higher the ratio, the less likely it is that the firm will need to seek external sources to cover current liabilities. For example, a firm with a current ratio of 2 would be able to see the value of its current assets (such as cash, cash equivalents, marketable securities, inventory and accounts receivable) decline by as much as half of their book value and still be able to "cover" its current obligations to short-term creditors without looking toward liquidating their fixed assets or seeking expensive external financing.

These liquidity measures presume that an asset is liquid if it can be turned into cash quickly, easily, and without an appreciable loss. Assets are listed on the balance sheet in the order of their liquidity, with the most liquid asset listed first. Cash is by definition the most liquid asset, while a building is considered to be somewhat illiquid. A building might be sold and turned into cash quickly, but

only if the owner were willing to incur a substantial probability of financial loss in the rapid liquidation of the asset. Other assets have varying degrees of liquidity. Inventory and accounts receivable are typically 
more liquid; equipment is typically less liquid. While measuring the time it takes to convert an asset to cash and the potential for appreciable loss during that conversion are estimates, the concept behind assessing and ranking the liquidity of assets held by a company in this way is generally agreed upon (Emery, 1984).

There are two main problems with static liquidity measures. First, static measures do not always provide accurate information about the likelihood that a firm will be able to meet its cash requirements because they may incorporate financial resources that are not easily convertible into cash without loss of value. Second, static measures do not recognize that some assets and liabilities are tied up in, and necessary for, ongoing operations.

It may be argued that higher static ratios protect creditors from loss severity after liquidation. That is, after the firm disposes of its assets, it uses the proceeds to repay its obligations. However, this is true only in so far as the firm's current assets are liquidated at or close to full book value. There are two issues here. First, with the exception of cash, current assets like accounts receivable and inventory rarely are sold for book value during liquidation. The fair market value at which they can be sold may be quite different from their historical book value. The second issue has to do with how the law treats a firm's liabilities under Chapter 7 liquidation. After liquidation, most current liabilities are quite far down the priority list for payment established by bankruptcy law. Therefore, the idea that unsecured accounts payable and notes payable would, in reality, receive a reasonable portion of the value of the liquidated current assets is questionable. The issue of liquidating at book value combined with the issue of priority is the reason creditors and investors prefer that the firm's current and quick ratios far exceed 1 . If the ratio is 2 or higher, this increases the probability that the firm's current assets will be sufficient to repay current liabilities following liquidation, even given the concerns outlined above.

Another problem with standard liquidity ratios lies in the assumption that higher ratios are positive signals for a company's short-term financial wellbeing. This assumption is not necessarily true. For example, a rising current ratio may be caused by an increase in accounts receivable generated not by increased sales, but rather by an increase in the age of the average account held by the firm. In such a case, the fair market value of the accounts receivable is actually likely to decline, because delinquency rates generally increase as the age of the accounts receivable increases. Under this condition, the firm is actually less likely to cover its current liabilities, not more, even though its current ratio is increasing. The same can be said for the impact of rising inventory on the current ratio. If inventory is increasing in response to increased unsold goods, then the fair market value of these goods is likely to be 
substantially lower than the stated book value. In this case, the higher current ratio is again a reflection of a lower, not a higher, level of liquidity.

Overall, the current and quick ratios provide an incomplete and potentially inaccurate assessment of the firm's liquidity as a going concern, even though they are of some use for assessing the value of current assets under conditions of liquidation. Ratios such as the current ratio and the quick ratio are more appropriately categorized as liquidation ratios than liquidity ratios. The difference is critical to the accurate assessment of a firm's incremental financial risk imputed by its higher levels of liquidity risk. To accurately assess liquidity, the current assets and liabilities used in the firm's operating cycle need to be differentiated from those current assets and liabilities that are not directly related to the firm's operations. The former do not represent liquid assets as long as the firm is a going concern. What is needed is a measurement technique that considers the liquidity of ongoing current assets used in the operating cycle separately from the other current assets held by the firm. The integrative approach to liquidity analysis is designed to accomplish just this goal.

\section{Integrative Measures of Liquidity}

Measuring the liquidity of a firm's operations is quite a different matter from measuring the liquidity of its assets or specific asset accounts. Integrative liquidity measures assess how liquid the firm during ongoing operations, not the liquidity of the firm after it has sold off current assets needed to maintain operations. In so doing, these measures should be able to provide investors and creditors with information regarding the ability of operations to sustain the firm without the need to liquidate productive assets or find external capital to fund operating needs. The integrative approach, first characterized by Shulman and Cox (1985) and Shulman and Dambolena (1986), categorizes the underlying balance sheet accounts of net working capital (NWC) into two distinctive components- one that focuses on financial liquidity and one that focuses on operating liquidity. This method provides to financial analysts, investors, and creditors a measure of the liquid balance of financial assets after operational needs have been met.

The first step in measuring the liquidity of a firm's operations is to break down the firm's NWC measure-an accounting item closely related to the firm's liquidity as measured by the current ratio-into two distinctive components: the financial component and the operating component. The financial component of the firm's NWC is the net liquid balance. The operating component of the firm's NWC is the working capital requirement. The process of transforming the firm's current ratio, which is a 
liquidation measure, into a disaggregated measure of the firm's operating and financial liquidity is summarized in Figure 1.

Figure 1

Disaggregating liquidity

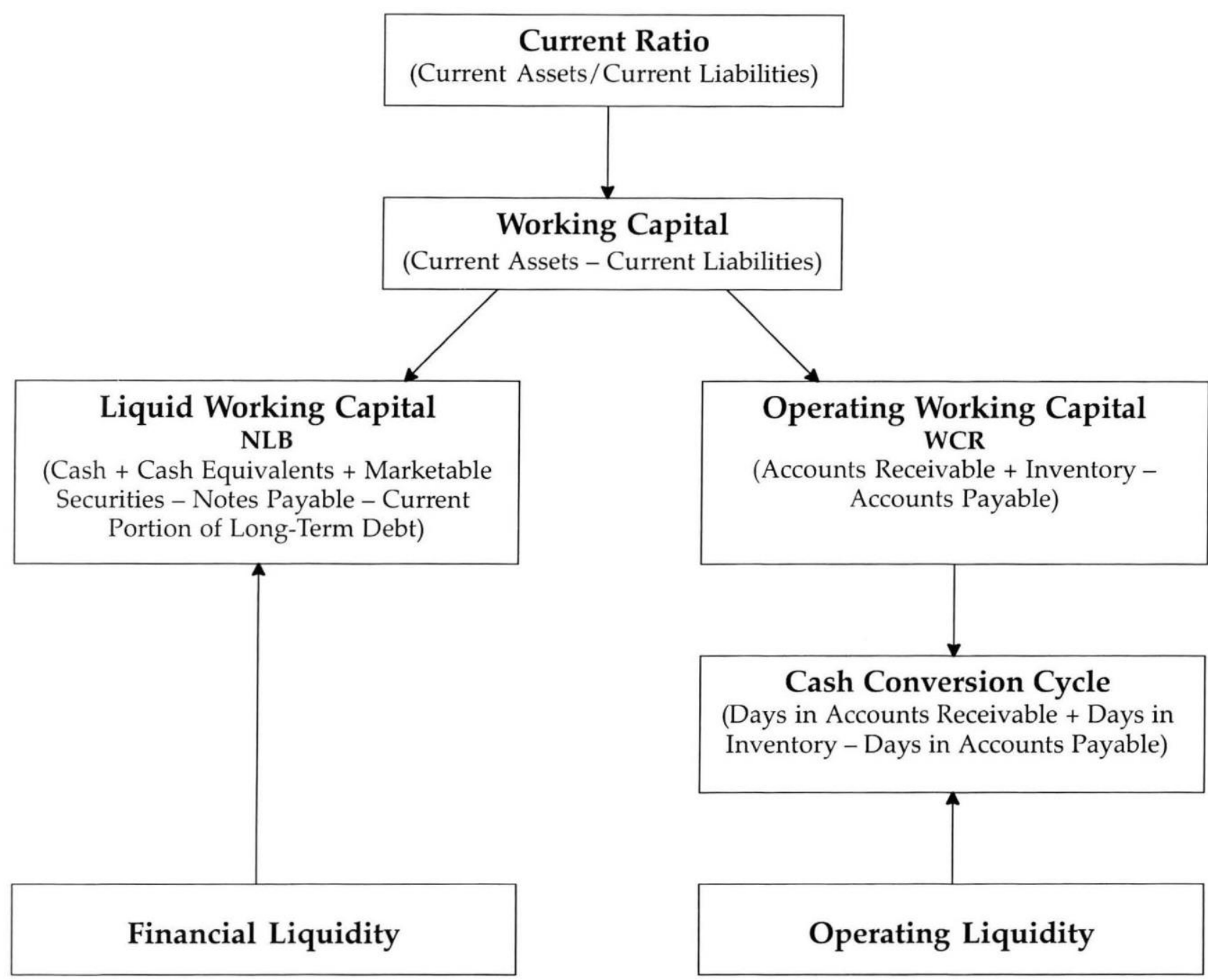

The liquid working capital component of NWC, also known as the net liquid balance or NLB, is the liquid balance of financial assets after operational needs have been met. It is defined as financial current assets less financial current liabilities. Financial current assets are cash, marketable securities, and cash equivalents, while financial current liabilities are equal to notes payable plus the current portion of long-term debt. As a result, NLB provides a direct link to the firm's liquidity position by measuring a firm's ability to cover financial current liabilities with the use of financial current assets. 
Since NLB does not include current assets tied up in operations, such as accounts receivable or inventories, higher levels of NLB always imply greater financial liquidity, unlike higher levels of the current ratio.

The operating working capital component of the firm's NWC, the working capital requirement or WCR, is defined as operating current assets less operating current liabilities, where operating current assets equal inventory plus accounts receivable and operating current liabilities are defined as accounts payable. As discussed previously, an increasing current ratio-and therefore its WCR-caused by growing inventory or accounts receivables does not always imply that the firm is more liquid. At times, it would in fact more than likely imply the opposite.

As a result, the WCR is not useful in its current form to measure a firm's operating liquidity directly. Furthermore, since it is a static measure, it does not measure both the timing and size of the cash flows that really determine the extent to which a firm's operations are liquid. What is needed is a mechanism for transforming the static measure of operating liquidity represented by the WCR into a dynamic measure of liquidity that captures the liquidity of these assets and liabilities in an ongoing operational setting. Richards and Laughlin (1980) suggest the use of the cash conversion cycle as a dynamic or a flow measure of operating liquidity. This flow measure of operating liquidity better incorporates both the timing and size of the cash flows. The process of transforming the WCR from a static measure into a dynamic measure is presented next.

First, remember that WCR is defined as inventory plus accounts receivable less accounts payable. If each of these accounts is examined in a dynamic setting, it is possible to see that WCR is directly related to the cash conversion cycle (CCC). The CCC measures the amount of time in days that it takes a firm to transform cash spent to purchase inventory for sale into cash collected from those sales. The CCC is defined as the inventory conversion period (ICP) plus the accounts receivable collection period (RCP) less the accounts payable deferral period (PDP). The ICP equals the number of days that the average inventory is held until it is sold. The RCP is the number of days that the average accounts receivable takes to be collected. Together, the firm's ICP and RCP equal the firm's operating cycle and represent the amount of time that the firm's operations take to turn inventory into finished goods, sell them, and collect the cash from those sales. Finally, it must be recognized that cash does not go out from the firm as soon as the inventory is purchased instead the firm typically assumes an accounts payable. The period of time between purchasing the inventory until the accounts payable is settled for cash is the accounts payable deferral period (PDP). Subtracting the PDP from the firm's operating cycle 
gives us the CCC, which is the appropriate measure of operating liquidity. The CCC is the measure that is used in the integrated model of the firm's liquidity to connect the firm's WCR to a measure of operating liquidity.

In sum, it is apparent that the NLB and the CCC are appropriate measures of the firm's financial liquidity and operating liquidity, respectively, as a going concern. The NLB and the CCC are linked to the current ratio, but differ in that they include only the financial and operating liquidity components of NWC available while the firm continues to operate. In the next section, each of these measures is compared.

\section{The Data Sample}

The primary data sample consists of all publicly traded restaurant and manufacturing companies with annual financial statements available on the Compustat database over the ten year period from 1994-2003. The four-digit SIC code 5812 (Restaurants and Eating Places) was used to identify the sample firms. This provided a total of 111 restaurant companies. Using the description of business variable in Compustat, the sample of restaurant companies was separated into two groups, those firms that were owner operated and those that were engaged in franchise activities. The sample consists of 36 firms primarily engaged as owner-operated restaurant companies and 75 restaurant companies primarily engaged in managing a franchise system. The owner-operated restaurants were separated from the restaurant franchise companies because franchise restaurant companies have a different business model, one of running a franchise system as opposed to a restaurant operation. As a result, there are differences in their asset and liability accounts. For example, owner-operated restaurants have low receivables, while restaurant franchisors tend to have higher levels of receivables from franchise fees due from the franchisees in their system. By analyzing these two groups separately, it is possible to show the importance of analyzing various measures of both operating and financial liquidity regardless of business structure. The results are not specific to restaurant operators.

In order to show that the results are not specific only to restaurant operators and franchisors, we also examined a sample of manufacturing firms. Manufacturing firms represent a major force in the U.S. economy. Understanding the impact of accurately assessing liquidity for these firms would be a critical test of any liquidity measurement framework. For instance, manufacturers typically have high levels of both inventory and receivables, unlike the restaurant operator and restaurant franchisor groups. The two digit SIC codes 20 through 39 were used to identify a broad sample of manufacturing 
firms. This resulted in a total of 2380 manufacturing firms in the sample with financial reports available during the ten-year sample period. Table 1 provides an indication of the relative sizes of the firms in the study using average total assets and average annual sale.

Table 1

Average total assets and sales

$\begin{array}{lccc}\text { Firm Type } & \begin{array}{c}\text { Average } \\ \text { Companies }\end{array} & \begin{array}{c}\text { Average } \\ \text { Total Assets } \\ \text { (in millions) }\end{array} & \begin{array}{r}\text { Annual Sales } \\ \text { (in millions) }\end{array} \\ \begin{array}{l}\text { Restaurants } \\ \text { Owner-operated }\end{array} & 36 & \$ 313.39 & \$ 477.95 \\ \quad \text { Franchisors } & 75 & \$ 310.38 & \$ 498.75 \\ \text { Manufacturing } & 2,380 & \$ 1,896.33 & \$ 1,779.48\end{array}$

The average total assets and average annual sales of the two groups of restaurant companies are fairly close in size. The owner-operated restaurant companies have a slightly higher average asset value and a slightly lower average annual sales than the franchisors. The values of both average annual sales and asset values for the sample of manufacturing firms are significantly higher than those of the restaurant sample. The fact that our restaurant samples have similar sizes makes comparisons of liquidity and the cost of financing operating liquidity fairly straightforward. The size differential between manufacturing firms and the restaurants is an issue only for the values of the firms' NLB, as the CCC is reported in days, not dollars, and the current and quick ratios are already normalized. To account for the differences in the dollar values of the NLB, both the raw values and the values adjusted for size using NLB divided by total assets as the comparison statistic are reported later (in Table 3).

For each company in the sample, the current and quick ratios, the NLB, and the CCC were calculated across the sample period to ascertain if there were any differences in firm liquidity based on the metric of liquidity employed. In addition, the opportunity cost of holding the operating working capital was estimated for each firm in order to determine the economic cost imposed by the firm's decision to hold operating current assets. While maintaining liquidity has positive signaling benefits regarding the firm's short-term financial risk, the cost of holding operating working capital has a negative impact on the value added to the firm in direct proportion to the economic cost of holding unproductive operating working capital. 


\section{Results}

Table 2 shows the current and quick ratios for each of the three groups of firms in our sample. When the standard static measures are examined to assess the firms' liquidity, manufacturing firms appear to be the most liquid, having current and quick ratios well above 2 . The restaurant franchisor and restaurant owner-operator groups seem to be quite illiquid. The current ratio for the restaurant franchisor group is barely above 1 , while the current ratio for the restaurant owner-operator group is below 1 . In addition, the quick ratios for both the restaurant franchisors and restaurant owneroperators are below 1 . These findings seem to bear out the presumption that firms engaged in either restaurant operations or franchising have high levels of short-term financial risk as measured by the commonly employed liquidity measures.

Table 2

Current and quick ratios, 1994-2003

\begin{tabular}{|c|c|c|c|}
\hline & $\begin{array}{c}\text { Restaurant } \\
\text { Owner-Operators }\end{array}$ & $\begin{array}{l}\text { Restaurant } \\
\text { Franchisors }\end{array}$ & $\begin{array}{c}\text { Manufacturing } \\
\text { Firms }\end{array}$ \\
\hline Current Ratio & 0.9201 & 1.0053 & 3.5211 \\
\hline Quick Ratio & 0.7374 & 0.8431 & 2.7223 \\
\hline
\end{tabular}

These results, however, do not show the whole picture. As discussed earlier, higher current and quick ratios do not necessarily imply that firms are liquid. In fact, due totheir poor construction and the economics of holding current assets, these ratios may provide perverse results. To gain a clearer picture of liquidity and the financial risk imposed on firms as a result thereof, the current ratio was disaggregated into the CCC (operating liquidity) and the NLB (financial liquidity). In so doing, it is possible to determine whether the source of any illiquidity lies in operations (operating liquidity) or in financing (financial liquidity).

The results in Table 3 provide a strikingly different picture of liquidity than those seen in Table 2 for our three groups of firms. First, the measure of operating liquidity, CCC, provides evidence that the group of firms constituting the restaurant owner-operators is the most liquid with a CCC of -2.764 days. Restaurant franchisors have a CCC of 29.892 days, and manufacturing firms have a significantly higher 120.339 days. Note that the current and quick ratios were very similar for the restaurant owneroperators and the restaurant franchisors, while their operating liquidity is somewhat different. The manufacturing firms that appeared to be quite liquid when measured by the current and quick ratios are 
here shown to have a substantial amount of illiquidity in their operations. Remember that the CCC, the preferred measure of operating liquidity, calculates in days the period between when cash is collected in the operating cycle and when it is dispersed from accounts payable. A positive number implies that the company takes more days to collect its cash than it has used to defer payments to their current account payable creditors. A negative number implies that the company is transferring cash through their operating cycle in fewer days than it is taking to pay off its accounts payable. For the CCC, the shorter (or lower the number of days), the better; having a negative number implies that the company's operating cycle is very short compared to its payable deferral.

Table 3

Cash conversion cycle and net liquid balance, 1994-2003

\begin{tabular}{|c|c|c|c|}
\hline & $\begin{array}{c}\text { Restaurant } \\
\text { Owner-Operators }\end{array}$ & $\begin{array}{l}\text { Restaurant } \\
\text { Franchisors }\end{array}$ & $\begin{array}{c}\text { Manufacturing } \\
\text { Firms }\end{array}$ \\
\hline Casl & -2.764 days & 29.892 days & 120.339 days \\
\hline Net Liquid Balance & $\$ 7.593$ million & $\$ 5.284$ million & $\$ 54.900$ million \\
\hline Net Liquid Balance/Total Assets & 0.0170 & 0.0242 & 0.0290 \\
\hline
\end{tabular}

A negative value is quite rare for the $\mathrm{CCC}$, since this requires that the sum of both the inventory conversion period and the receivables collection period to be less than the payabies deferral period. One might expect there to be a fairly close mapping of the payable and receivable periods, since they represent the flip side of the same coin in a business relationship. Even if a firm can manage to collect receivables in a timelier manner and delay payables, there is still the time necessary to transform inventory into finished goods and sell them. The addition of the inventory conversion period to the receivable collection period makes it difficult to find instances of negative CCCs.

As shown in Table 4, both the restaurant owner-operators and manufacturing firms are collecting their accounts receivable faster than they are paying out their accounts payable on average. Unfortunately for the restaurant franchisors, this is not the case. The reason lies in the nature of the restaurant franchisor firms' relationship with their accounts receivable creditors. Accounts receivable for the restaurant franchisors are the company's franchisees. Collecting fees in these environments often takes longer as the payment value is based not on a good or service transaction, but on reported sales over the previous period, and therefore will take longer to agree upon and collect. Restaurant owneroperators have a distinct advantage here over their franchisor counterparts. Owner-operators collect cash for their sales, while franchisors must wait for their franchisees to determine the amount owed and 
remit. Our group of owner-operators has a very low receivables collection period because of this fact. The only reason they do not have an effective zero collection period is that some firms in this group have a few franchisees and some have corporate accounts that pay on credit terms. However, the fact that this group's days in receivables is 57 and 80 days shorter than the franchisor and manufacturing firms, respectively, is one of the main reasons for the negative CCC observed here. This explains why restaurant owner-operators are very liquid when the focus is on their operating liquidity and provides a very different story from the one found when liquidity is examined using either the current or quick ratio.

Table 4 Components of the cash conversion cycle, 1994-2003

\begin{tabular}{|c|c|c|c|}
\hline & $\begin{array}{c}\text { Restaurant } \\
\text { Owner-Operators }\end{array}$ & $\begin{array}{l}\text { Restaurant } \\
\text { Franchisors }\end{array}$ & $\begin{array}{c}\text { Manufacturing } \\
\text { Firms } \\
\end{array}$ \\
\hline Days in Inventory & 7.84 & 8.79 & 91.74 \\
\hline Days in Receivables & 5.50 & 62.31 & 85.86 \\
\hline Days in Payables & 14.59 & 32.98 & 180.49 \\
\hline
\end{tabular}

Financial liquidity as measured by the NLB provides further evidence that restaurant owneroperators and franchisors are not less liquid than manufacturing firms. Remembering that the NLB should be positive under the assumption that a firm should have sufficient cash on hand to meet its short-term financial obligations from notes payable, we found that all firms in the sample have quite reasonable buffers between their short-term financial obligations and their cash on hand to meet those obligations. This is true whether the raw dollar amount or the percent of the NLB buffer against total assets is examined. However, while it has been shown that both restaurant franchisors and operators have similar NLB, manufacturing firms have a level about eight to ten times higher. Once size differences are controlled for by dividing the NLB by total assets, financial liquidity across the three groups is quite similar (as was shown in Table 3).

At first glance, manufacturing firms seem more financially liquid and, from a pure liquidity standpoint, they are. However, excessive holdings of cash place a burden on firms because they represent assets that must be financed but that do not earn a rate of return in excess of the required return on the firm's capital. Therefore, while the extremely high level of liquidity for these firms is a positive from a financial risk standpoint, it is a negative from a financial valuation standpoint. 
The last issue considered here is related directly to the issue of financing working capital in that the negative cash conversion cycle of restaurant owner-operators has another implication beyond the fact that is makes them highly liquid from an operating perspective. A lower cash conversion cycle also means that the firm incurs lower financing costs on their operating working capital. In Table 5, an estimate of the average cost to finance operating working capital was calculated for firms in each of the three groups. An estimate of 10 percent as the firm's weighted average cost of capital (WACC) was used and this was applied to the balance financed in each of the firm's components of the CCC. That is the cost of inventory plus the cost of receivables less the cost of payables. The cost of inventory was computed as the days in inventory times inventory times the WACC divided by 365 . Each of the other components was computed similarly. Manufacturing firms, because they need to finance their sizable operating capital for 120.339 days on average, must incur annually a \$7.1035 million dollar financing cost. Restaurant franchisors have a lower CCC and hold a smaller raw dollar amount of operating capital than the manufacturing firms, but still incur a positive cost to finance their operating working of $\$ 75,400$ per year. However, since they have a negative CCC, restaurant owner operators have the additional benefit of gaining free financing for their operating working capital. In fact they spin off a small profit of $\$ 9,600$ per year on average. While not significant, it does mean that these firms have an advantage over the others in our sample as they need not "make-up" the financing costs incurred by holding dead weight loss working capital.

Table 5

Cost of carrying operating capital, 1994-2003

\begin{tabular}{|c|c|c|c|}
\hline & $\begin{array}{c}\text { Restaurant } \\
\text { Owner-Operators }\end{array}$ & $\begin{array}{l}\text { Restaurant } \\
\text { Franchisors }\end{array}$ & $\begin{array}{c}\text { Manufacturing } \\
\text { Firms }\end{array}$ \\
\hline $\begin{array}{l}\text { Cost of Carrying } \\
\text { Operating Capital }\end{array}$ & $-\$ 9,600$ & $\$ 75,400$ & $\$ 7,103,500$ \\
\hline
\end{tabular}

\section{Conclusion}

Many financial analysts, creditors, and managers use static measures of liquidity such as the current and quick ratios to gauge a firm's ability to meet cash obligations as they come due. However, these static measures are only generally useful to estimate the firm's ability to cover short-term obligations, given that they presume (1) the firm liquidates current assets required for operations and (2) this liquidation occurs at or near book value. These measures are not as useful to assess the ability of the firm to cover current obligations while operating, and therefore they should not be used as an 
indicator of firm liquidity in a going concern. This issue was specifically problematic when evaluating restaurant and manufacturing companies. It was found that, within an integrative liquidity framework, the cash conversion cycle (a measure of the firm's operating liquidity) and the net liquid balance (a measure of the firm's financial liquidity) provide information about the firm's ability to cover obligations while continuing to operate beyond that provided by the static measures.

Specifically, when evaluated under this integrative framework, restaurant owner operators were shown to be as liquid as both restaurant franchisors and manufacturers, based on their financial liquidity, and more liquid than both when assessing operating liquidity. These results provide a drastically different view of owner-operator restaurant liquidity than those produced from current and quick ratios. This is an important finding for managers and investors as it may have a substantial impact on their financing costs and required returns from equity investors. Thus, it is important for financial analysts, creditors, and managers to examine both dynamic liquidity measures and static measures when evaluating the financial liquidity and short-term default risk of restaurant owner-operators. Furthermore, operating liquidity measures and financial liquidity measures provide different pictures. The use of both is important in determining the overall liquidity of the firm. Therefore, when evaluating short-term liquidity, we must pay careful attention to each component of the integrative framework to establish what changes, if any, have occurred in the liquidity position over time and what the implications are for the firm's financial and operating liquidity.

\section{References}

Emery, G. W. (1984). Measuring short-term liquidity. Journal of Cash Management, 4 (July/August), 7-

14.

Kamath, R. (1989). How useful are common liquidity measures? Journal of Cash Management, 9 (January / February), 24-28.

Richards, V. D., \& Laughlin, E. J. (1980). A cash conversion cycle approach to liquidity analysis. Financial Management, 9 (1), 32-38.

Shulman, J. M., \& Dambolena, I. G. (1986). Analyzing corporate solvency. Journal of Cash 
Management, 6 (September I October), 35-38.

Shulman, J. M., \& Cox, R. A. K. (1985). An integrative approach to working capital management. Journal of Cash Management, 5 (November / December), 64-67. 